\title{
THE BLUE FUTURE OF INDONESIA: Mungkinkah Merealisir Visi Ekonomi Indonesia Berbasis Kelautan?
}

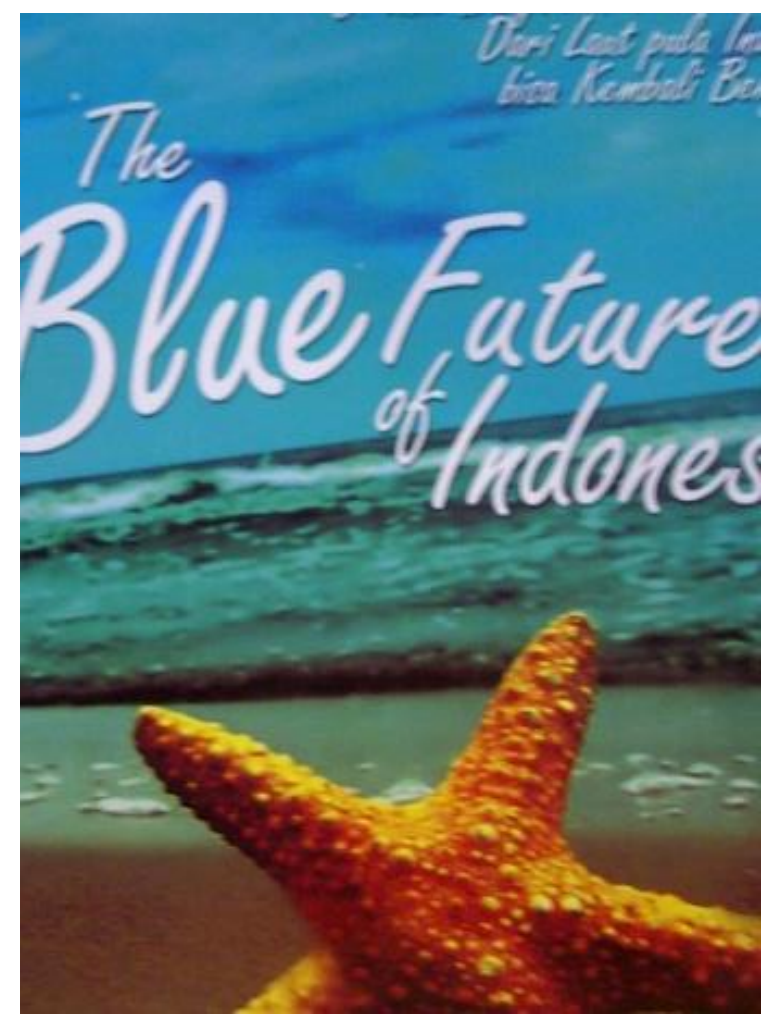

Judul : The Blue Future of Indonesia

Penulis : Rokhmin Dahuri

Penerbit : Roda Bahari dan Rokhmin Dahuri Institute, Maret 2013

Tebal : XIV + 320 hal

ISBN : :978-602-18871-4-1

Tidak mudah menemukan kembali buku semacam ini yang secara praktis tapi inspiratif mengulas mengenai salah satu kekuatan geo-strategis dan geo-ekonomis Indonesia khususnya di bidang kelautan. Pengetahuan mengenai "kejayaan” nenek moyang kita sebagai penakluk bahari memang sudah sering kita dengar dan dengungkan, akan tetapi menyadari dan kemudian mengaplikasikan dalam bentuk penggalian potensi rupanya masih jauh dari kehidupan keseharian kita. Melalui buku ini, mantan Menteri Kelautan dan Perikanan pada masa Kabinet Indonesia Bersatu (Presiden KH. Abdurrahman Wahid) dan Kabinet Gotong Royong (Presiden Megawati Soekarnoputri) periode 4 Juni 2001 sampai dengan 20 Oktober 2004 ini; mencoba membuka mata, memotivasi dan memperluas perspektif bahwa kita sebagai bangsa kepulauan yang dikelilingi oleh laut dengan segala kekayaannya - belumlah menggali potensi tersebut secara maksimal. Sebagai ahli di bidang kelautan, Rokhmin Dahuri mampu membawa kita pada sesuatu yang tidak kita perhatikan dengan serius meskipun hal itu ada di depan mata kita. Ironis sekaligus menantang, terutama dalam konteks bangsa Indonesia menghadapi era persaingan global. 
The Blue Future of Indonesia diawali dengan slogan pada halaman pertama "Di laut Bangsa ini pernah Jaya. Dari Laut pula Indonesia bisa Kembali Berjaya!“. Suatu ungkapan optimis yang mengawali bab-bab yang menantang sekaligus mengharukan.

Bab pertama dibuka dengan Visi Ekonomi Indonesia Berbasis Kelautan Indonesia - Laut Sebagai Keunggulan Kompetitif.

Bagian Kedua berjudul Indonesia Memiliki Kekuatan Bangsa Besar terdiri dari 7 sub judul, yaitu Sistem Agribisnis Terpadu, Potensi Kelautan dan Daya Saing Bangsa, Keunggulan Kompetitif Laut, Mengapa Harus menjadi TKI?, Perang Melawan Pengangguran, Pertumbuhan Berkualitas dan Reorientasi Pembangunan Nasional.

Bab ketiga Merebut Kejayaan Indonesia terdiri dari 4 sub judul yaitu Potensi Kejayaan Indonesia, The Blue Economy of Indonesia, Tren Kerusakan Laut dan Akar Permasalahan Lingkungan.

Bab keempat mengulas mengenai Menggabungkan Ekonomi Hijau dan Biru dengan 9 subbab yaitu Peran Indonesia Dinanti Dunia, Membangun Sektor Perikanan untuk Kesejahteraan Bangsa, Potensi dan Peluang Pembangunan Perikanan, Impor Garam dan Masa Depan Udang, Status Produksi dan Kebutuhan Garam Nasional, Peningkatan Produksi Garam Nasional, Membangun Industri Udang Nasional, Penyebab Rendahnya Kinerja Tambak Udang dan Solusi Permasalah.

Bab kelima merupakan Studi Kasus Membangun Pantura Jawa Barat, terdiri dari 4 sub-bab yaitu Kondisi SDA, Infrastruktur dan SDM, Kinerja Ekonomi Pantura, Permasalahan dan Tantangan Pembangunan Pantura dan Road Map Pembangunan Pantura Jawa Barat.

Bab keenam adalah Road Map Pembangunan Perikanan yang memuat 2 sub bab yaitu Perikanan Tangkap dan Perikanan Budidaya.

Bab ketujuh meyorot mengenai Membangun Kedaulatan Pangan Nasional meliputi pemikiran dalam 4 sub-bab yaitu Rantai Suplai Distribusi Konsumsi, Politik-Ekonomi, Indonesia yang Menganggumkan dan Potensi Produksi.

Bab kedelapan Menolong para Nelayan Indonesia memaparkan 5 sub-bab yaitu Strategi Membantu Nelayan, Akar Masalah Kemiskinan Nelayan dan Solusinya, Akar Kemiskinan Nelayan, Jurus Menyejahterakan Nelayan dan Penyempurnaan Program.

Bagian kesembilan Laut, Ikan dan Ketahanan Pangan Indonesia memuat 3 sub-bab yaitu Produksi Pangan Indonesia, Produksi Komoditas Non-Pangan dan Potensi Ekonomi.

Bagian kesepuluh membahas mengenai Menuju Industri Perikanan Indonesia dengan 5 subbab yaitu Menuju Perikanan Industrial, Anatomi Permasalahan Illegal Fishing dan Solusinya, Seluk Beluk Pencurian Ikan, Penyebab IUU Fishing dan Strategi Penanggulangan IUU Fishing. 
Bagian kesebelas adalah mengenai Mempersiapkan Diri dalam Pergantian Kekuasaan Dunia berupa 2 sub-bab yaitu Krisis Ekologi dan Sosial dan Jalan Baru untuk Dunia.

Bagian keduabelas mengenai The Celestial Economy berupa 3 sub bab yaitu Gagalnya Kapitalisme, Prinsip Dasar the Celestial Economy dan Pembangunan Berkelanjutan dalam Perspektif Islam.

Buku diakhiri dengan epilog yaitu Momentum Kebangkitan Umat Islam dengan 6 sub-bab yaitu Momentum Kebangkitan, Menuju Indonesia Maju, Adil, Makmur dan Berdaulat, Faktorfaktor Penentu Daya Saing, Perangkap Ketergantungan Indonesia, Manajemen Teknologi dan Inovasi serta Pembangunan Supra Struktur yang Kondusif.

\section{The Blue Economy: Potensi Kejayaan Indonesia}

PEMSEA (Partnerships in Environmental Management for the Seas of east Asia, 2011) mendefinisikan blue economy sebagai suatu model ekonomi yang menerapkan teknologi, pembangunan infrastruktur, konstruksi, sistem transportasi, mekanisme keuangan yang inovatif dan pranata kelembagaan yang proaktif guna mewujudkan dua tujuan, yaitu melindungi ekosistem pesisir dan lautan serta secara simultan mengembangkan potensinya untuk pembangunan berkelanjutan, termasuk peningkatan kesejahteraan umat manusia dan mengurangi resiko-resiko lingkungan serta kelangkaan-kelangkaan ekologis (hal 58).

Pada tataran praktis, blue economy memberikan pedoman pembangunan kelautan, antara lain: (a) memelihara dan meningkatkan daya dukung eko sistem pesisir dan lautan agar mampu menyediakan bahan pangan, energi, SDA dan ruang serta kualitas hidup yang sehat, nyaman, lestari; (b) laju pemanfaatan SDA harus tidak melebihi kemampuan pulih dari SDA tersebut; (c) eksploitasi SDA tidak terbarukan (batu bara, tambang) mesti dilakukan secara ramah lingkungan; (d) semua kegiatan ekonomi dan manusia harus diusahakan tidak banyak membuang limbah (zero-waste); (e) rehabilitasi semua eksosistem alam; (f) semua aktivitas pembukaan lahan, reklamasi, dll harus dikerjakan sesuai dengan struktur, karakteristik dan dinamika alam setempat; (g) upaya mitigasi dan adaptasi terhadap perubahan iklim global; (h) harus menurunkan total permintaan manusia terhadap SDA.

Buku ini terutama ingin menegaskan bahwa ditengah berbagai tantangan kemiskinan di Indonesia, pengangguran terbuka dan setengah terbuka yang amat besar, rendahnya produktivitas, efisiensi bahkan kolusi, korupsi, nepotisme serta harapan rakyat akan kehidupan yang aman, damai sejahtera - sesungguhnya harapan itu dapat dipenuhi dari industri berbasis sumber daya alam dan jasa-jasa lingkungan (environmental services) kelautan. Industri yang meliputi sebelas sektor utama, yaitu (1) perikanan tangkap, (2) perikanan budidaya, (3) industri 
pengolahan hasil perikanan, (4) industri bioteknologi kelautan, pariwisata bahari, (5) pertambangan dan energi, (6) pariwisata bahari, (7) hutan mangrove, (8) perhubungan laut, (9) sumberdaya wilayah pulau-pulau kecil, (10) industri dan jasa maritim dan (11) sumber daya non konvensional seperti deep sea water industries, hydrothermal vents dan benda-benda berharga asal muatan kapal tenggelam. Dan bukan terutama industri manufaktur canggih (kapal terbang, otomotif, dll) yang sudah dikuasai oleh negara-negara besar.

Indonesia saat ini merupakan produsen ikan terbesar kelima di dunia dengan volume 7.68 juta ton (FAO, 2012) jika ditingkatkan lagi dapat merebut posisi China yang saat ini merupakan produsen ikan nomor satu dunia -dengan luas laut dan panjang garis pantai lebih kecil dari Indonesia. Potensi ekonomi perikanan yang lain adalah tambak udang dan rumput laut. Lahan potensial 1,2 juta ha ternyata baru diusahakan 400.000 ha dengan produktivitas rata-rata 0,6 ton/ha/tahun. Selain potensi lain yaitu potensi ekonomi industri bioteknologi kelautan berupa industri farmasi, kosmetika, bioenergi dan ekonomi pariwisata, perhubungan laut, jasa penyediaan tenaga kerja pelaut, jasa maritim (galangan, pabrik peralatan, mesin perikanan, dll). Ekonomi kelautan semakin strategis bagi Indonesia seiring dengan pergeseran pusat ekonomi dunia dari poros Atlantik ke Asia Pasifik - yang akan menyangkut $70 \%$ perdagangan dunia yang 45\% nya ditransportasikan melalui laut. Kondisi Indonesia yang secara geo-ekonomi paling strategis ini harus dapat dimanfaatkan - agar tidak hanya menguntungkan negara tetangga Singapura, Hongkong, Jepang dan China.

Penulis juga menegaskan pemikiran Prof Michael Porter (2009) mengenai strategi mengembangkan daya saing bangsa, yaitu (1) blue ocean strategy dan (2) dengan menghasilkan produk dan jasa yang dibutuhkan manusia sejagat raya, yang beberapa bangsa sudah memproduksinya. (hal 25).

\section{Pemikiran Kelautan vs Pemikiran Spiritual Ekonomi}

Jika dicermati buku ini tidak hanya berisi mengenai penegasan kedaulatan bangsa Indonesia atas batas tanah dan laut (melalui Deklarasi Djoeanda 13 Desember 1957), atau peran strategis laut yang baru mendapat perhatian serius negara pada masa pemerintahan Abdurrahman Wahid dan Megawati, atau kekayaan laut baik berupa SDA terbarukan (seperti perikanan, teurmbu karang, hutan mangrove, rumput laut, dan produk bioteknologi), SDA tak terbarukan (seperti minyak dan gas bumi, timah, biji besi, bauksit dan mineral lain), energi kelautan (seperti pasang surut, gelombang, angin dan OTEC - Ocean Thermal Energy Conversion), jasa-jasa lingkungan kelautan seperti untuk pariwisata bahari, transportasi laut, sumber keragaman hayati serta plasma nuftah. Termasuk peran sentral dalam pengendalian dinamika iklim global, siklus hidrologi, 
siklus biogeokimia, penetralisir limbah dan sistem penunjang kehidupan yang membuat sebagian besar permukaan bumi layak dan nyaman dihuni. Segala hal tersebut merupakan potensi yang dapat didayagunakan untuk kemajuan dan kesejahteraan bangsa.

Akan tetapi penulis beranjak lebih jauh. Tidak hanya laut sebagai tulang punggung Indonesia tetapi juga menyinggung sistem ideologi pembangunan dunia. Hingga di sini penulis menyatakan "posisinya" dengan menawarkan the Celestial Economy bersumberkan Islam sebagai alternatif sistem kapitalis yang dianggap gagal. Pada prinsipnya The Celestial Economy menolak sistem ekonomi buatan manusia yang hanya ditujukan untuk mengejar kesejahteraan material (fisik), maka dalam sistem ekonomi Islam yang menjadi tujuan adalah agar manusia mendapatkan kesejahteraan material dan spiritual secara seimbang (the true well being) dan kehidupan yang baik (hal 262). Pelaksanaannya mengutamakan persaudaraan, dan keadilan sosial-ekonomi ketimbang persaingan saling menjatuhkan. Dengan kata lain penulis menggarisbawahi pentingnya membangun suatu model pembangunan berkelanjutan dalam perspektif Islam - yang pada dasarnya juga beranjak dari kajian-kajian Barat mengenai batasbatas pertumbuhan. Perspektif Islam menegaskan aspek kelemahan manusia yaitu "keserakahan" yang mengakibatkan distribusi SDA tidak adil bagi yang lain. Dalam skala lebih besar, keserakahan bangsa industri maju menyebabkan ketimpangan dan kemiskinan bangsa negara sedang berkembang. Suatu perspektif yang dapat dipahami mengingat pergumulan penulis sebagai umat Islam dan harapan akan visi yang dapat dikomunikasikan terhadap mayoritas warga bangsanya.

\section{Catatan Akhir}

Sebagai sebuah buku visi dan strategi mengenai pembangunan kelautan Indonesia, buku ini patut dibaca karena sekali lagi menyadarkan "harta karun" kelautan yang ada di depan mata yang menunggu tangan-tangan dingin terampil mau mengolah demi kesejahteraan rakyat Indonesia. Fakta fisik berupa wilayah laut sangat luas $(5,8$ juta $\mathrm{km} 2)$ yang merupakan tiga perempat dari total wilayah Indonesia plus secara material potensi kelautan yang mencapai Rp 7200 trilyun per tahun yang dapat memberi lahan dan lapangan kerja bagi 40 juta orang jika diberdayakan serta berbagai strategi yang dijabarkan (ekonomi hijau dan biru) -- mampukah "menggerakkan" para pelaku ekonomi dan usaha Indonesia?

Sebuah pertanyaan besar menggantung dan buku ini merupakan salah satu usaha dari putera Indonesia untuk "membuka" mata bangsanya akan mandat dan tugas besar membangun kelautan Indonesia. 
Salah satu kelemahan buku jika boleh menjadi catatan adalah tidak adanya gambar visual yang disertakan karena barangkali pada awalnya tulisan dimaksud lebih sebagai catatan pemikiran lintasan permenungan penulis. Juga tidak ditemukannya daftar singkatan serta Indeks, yang bagi pembaca yang tidak akrab dengan singkatan atau istilah dunia Kelautan akan mengalami kesulitan. Namun kekurangan ini tidaklah mengurangi kebebasan imajinasi pembaca, justru dapat mendorong pemikiran inspiratif.

Selamat membaca!

\section{V.L. Sinta Herindrasti}

